ALICJA STAŃCO

Uniwersytet Mikołaja Kopernika

\title{
The troubles. Terroryzm w ulsetrze: po dwóch stronach barykady
}

\section{Rys historii}

K onflikt w Ulsterze wydaje się najbardziej znanym i najszerzej opisywaInym konfliktem związanym z terroryzmem w Europie. Zdaje się nawet być częścią tożsamości brytyjsko-irlandzkiej. Rozpoczął się już w 1171 r., gdy Irlandia przeszła pod panowanie Wielkiej Brytanii na ponad 800 lat. W trakcie tego panowania w Irlandii osiadali się Anglicy i Szkoci, którzy w większości byli wyznania protestanckiego ${ }^{1}$. Z ubiegiem czasu coraz wyraźniejsze były granice między protestantami i katolikami, z równolegle biegnącym podziałem etnicznym na przybyszów i rdzennych, a te z kolei z podziałem na unionistów i lojalistów oraz republikanów². Granice te były dodatkowo potęgowane przez władze Królestwa, które imigrantom gwarantowały prawa ekonomiczne i polityczne, co skutkowało znacznymi

Wielka Brytania zachęcała do migracji obiecując obywatelom Królestwa konfiskowane ziemie rdzennych Irlandczyków.

W związku z tym, że zdecydowana większość protestantów to imigranci i unioniści, a większość katolików to rdzenni mieszkańcy wyspy i republikanie, często nazwy te stosuje się wymiennie zrównując: protestant = lojalista = unionista = imigrant na wyspie; katolik = republikanin = nacjonalista = rdzenny mieszkaniec wyspy. $\mathrm{W}$ swojej pracy chcąc podkreślić, że jest to konflikt polityczny, o przynależność państwową, a nie religijny unikam stosowania tych nazw wymiennie, używając określeń republikanin, nacjonalista, unionista, lojalista. 
dysproporcjami w statusie ekonomicznym i poziomie życia między wcześniej nakreślonymi grupami mieszkańców. Obecnie Irlandia Północna jest podzielona pomiędzy dwa państwa: Republikę Irlandii i Wielką Brytanię. Zamieszkuje ją prawie 1759000 ludzi, z czego protestanci stanowią ok. $56 \%$, a katolicy ok. $38 \%$. Stolicą jest Belfast ${ }^{3}$.

Ulsterscy republikanie wielokrotnie walczyli o odzyskanie niepodległości, bądź potem o przynależność do Republiki Irlandii. W 1641 r. wybuchło w Irlandii powstanie antyangielskie. Zostało krwawo stłumione przez wojska Oliviera Cromwella, a ucisk Irlandczyków się zwiększył. W 1652 r. Parlament Brytyjski uchwalił Akt zasiedlenia, który karał uczestników powstania licznymi egzekucjami. 36 lat później (w 1688 r.), Irlandczycy opowiedzieli się za Jakubem II. 12 lipca 1690 r. irlandzka armia została pokonana, a rok później (13.10.1691 r.) został zawarty traktat w Limerick, który w pełni oddawał kraj we władanie protestantów. W 1801 r. zawarty został Akt Unii, na którego mocy Irlandia została wcielona do Królestwa. 24 kwietnia 1916 r. wywołano Powstanie Wielkanocne ${ }^{4}$ (trzecie po powstaniach w 1798 r. i 1848 r.), które upadło 6 grudnia 1921 r. Podczas powstania Patryk Pearse odczytał proklamację Republiki Irlandii. Ulster został podzielony, a w $1925 \mathrm{r}$. została ostatecznie ustalona granica między hrabstwami. Rdzenni Irlandczycy byli zdominowani w kwestiach gospodarczych, edukacyjnych i politycznych. Powstał północnoirlandzki parlament, Stormont ${ }^{5}$, jednakże prawo do głosowania w wyborach rdzenni prawie nie posiadali ${ }^{6}$. Kolejnym utrudnieniem dla walczących o jedność wyspy był uchwalony przez Stormont w 1922 r. Akt specjalnych uprawnień $^{7}$, a następnie w 1936 r. Akt o porządku publicznym ${ }^{8}$. W 1968 r. roz-

Por. V. Grotowicz; Terroryzm w Europie Zachodniej wimię narodu i lepszej sprawy; s. 315-334. Głównymi organizatorami powstania było Irlandzkie Bractwo Republikańskie. Por. J. Bowyer Bell; Terror w Irlandii 1916-1923 [w:] Encyklopedia terroryzmu; s. 66-67.

Nazwa pochodzi od dzielnicy Belfastu, w której się znajduje.

Prawo do głosowania posiadali właściciele mieszkań, ale nie podnajemcy. Skutkowało to tym, że głosować mogli bogatsi imigranci, ale biedniejsi rdzenni mieszkańcy wyspy nie. To tylko jedno z ograniczeń politycznych. Istniały także inne gratyfikacje, przyznające mandaty imigrantom: zasada tzw. bussines premises vote, graduate vote, stosowano także metodę gerrymanderingu na ich korzyść.

Akt ów uprawniał ministra spraw wewnętrznych na aresztowanie każdego, kto popełni przestępstwo, nie przewidziane przez ustawę, przeciw protestanckiemu porządkowi- minister sam decydował jaki czyn jest przestępstwem. Akt miał być potem wykorzystywany do walki z IRA, lecz sądy i organy ścigania błędnie go interpretowały nadużywając prawa, co stało się później jednym z powodów wybuchu konfliktu w Ulsterze.

8 Akt zakazywał marszów, zgromadzeń i demonstracji (w tym wszelakich plakatów czy napisów na murach). Udział w nich podlegał karze aresztu lub grzywny (co zamknęło 
poczęła się fala demonstracji, które szybko rozprzestrzeniły się na całą Północną Irlandii. Skutkiem było wprowadzenie wojsk brytyjskich. Wybuchy stały się codziennością, a w dzielnicach powstawały strefy zakazane. W marcu, po 30 stycznia 1972 r. (Krwawej Niedzieli), zawieszony został Stormont i po uchwaleniu tzw. direct rule władzę przejął brytyjski rząd ${ }^{9}$. W 1973 r. odbyły się wybory do nowego Zgromadzenia Północnoirlandzkiego, które stworzyli umiarkowani republikanie i lojaliści (stworzono także Radę Irlandii). Mimo wielu prób z różnych stron, w tym brytyjskich polityków, pokój został osiągnięty dopiero w 1984 r., odbyły się kolejne wybory do Zgromadzenia, w których $10 \%$ mandatów zdobyło Sinn Fein ${ }^{10}$. Rok później podpisano porozumienie oraz powstała Międzynarodowa Konferencja Pokojowa Brytyjsko-Irlandzka ${ }^{11}$. W grudniu 1993 r. premierzy Irlandii i Wielkiej Brytanii podjęli rozmowy pokojowe, których efektem była Deklaracja z Downing Street ${ }^{12}$. W 1994 r. przekonano IRA do zawieszenia broni na czas nieokreślony, ekstremiści lojalistyczni kontynuowali działania terrorystyczne. Po dwóch latach IRA wznowiła działalność (powtórne zawieszenie broni w lipcu 1997 r.). W Wielki Piątek 1998 r. podpisane zostało Porozumienie Wielkopiątkowe, zawarte między rządami Wielkiej Brytanii i Irlandii i najważniejszymi partiami irlandzkimi, jednak nie zakończyło konfliktów. Początkiem 2000 roku Wielka Brytania zawiesiła autonomię Irlandii Północnej z powodu nierozwiązanej kwestii złożenia broni przez IRA. Porozumienie zostało zagrożone, jednakże IRA wydała oświadczenie ${ }^{13}$ o zakończeniu działań i wpuściła komisję kontrolującą

drogę pokojowego wyrażania sprzeciwu przez katolików, ale także zatrzymało marsze protestantów - choćby Zakonu Orańskiego). Z drugiej strony marsze często były przyczyną wybuchów zamieszek, gdzie często sami lojaliści wyręczali policję w zatrzymywaniu demonstrantów.

Miało to być rozwiązanie tymczasowe. Idea rządów bezpośrednich nie przyniosła poprawy sytuacji. Rok 1972 okazał się najkrwawszym w historii Ulsteru. Pochłonął ok. 467 ofiar.

Było to polityczne skrzydło IRA. Na jej czele wówczas stał Gerry Adams. Partia jest odnogą założonego w 1858 r. Irlandzkiego Bractwa Republikańskiego.

11 W skład Konferencji wchodzili przedstawiciele Republiki Irlandii, Irlandii Północnej i Wielkiej Brytanii. Jej celem była zmiana prawa oraz złagodzenie konfliktu między unionistami i republikanami. Rozwiązanie zadowalające dla polityków, nie było takim dla działaczy żadnej ze stron - ataki terrorystyczne trwały dalej.

Deklaracja stanowiła, iż tylko sami Irlandczycy są uprawnieni do domagania się samostanowienia i tylko oni opierając się na przyzwoleniu obywateli Północy i Południa mogą zjednoczyć Irlandię. Deklaracja jednak nie znalazła aprobaty u ugrupowań skrajnych.

13 Oświadczenie IRA, źródło: http://news.bbc.co.uk/1/hi/northern_ireland/4724599. stm. 
rozbrojenie. Problem terroryzmu jednak nie zniknął. Nadal aktywne są odłamy IRA (PIRA, CIRA, RIRA) oraz organizacje lojalistyczne, które toczą też walki między sobą.

Przez czas trwania konfliktów powstały także liczne ruchy i organizacje, które miały załagodzić konflikt: Towarzystwo Zjednoczonych Irlandczyków (1791 r.) republiki, Ruch Fenian (lata 50. XX wieku), Home Rule Party (1877 r.) Karola Stewarta Parnella, Gealic League (1883r.), z którego wywodzi się Sinn Fein ${ }^{14}$ (1898r.), Stowarzyszenie Praw Obywatelskich (CRA; 1966 r.).

\section{Po jednej stronie: Republikanie}

Najszerzej znaną organizacją terrorystyczną republikanów w Irlandii Północnej jest IRA. Powstała jako pierwsza w obronie praw rdzennych mieszkańców wyspy, lecz z czasem uległa też rozłamom, w wyniku których powstały Real IRA (RIRA), Provisional IRA ${ }^{15}$ (PIRA), Continuity IRA (CIRA). Obok istnieje Irlandzka Armia Narodowo - Wyzwoleńcza (INLA) i jej frakcja GHQ (INLA - GHQ). IRA jest najstarszą organizacją terrorystyczną na wyspie, a nawet na całym kontynencie. Długi staż koreluje bardzo dobre uzbrojenie i wyszkolenie. Współczesny etap wojny z IRA rozpoczął się w 1969 r., gdy rząd Irlandii Północnej przestał panować nad starciami między republikanami i unionistami, a Londyn wprowadził tam swoje wojsko i przejął rządy. Przechodząc do omówienia konkretnie organizacji terrorystycznych w Ulsterze, które walczą o przyłączenie tego regionu do Republiki Irlandii.

Genezy IRA (Irish Republican Army) szukać należy w wojskowej formacji Irish Volunteers. Nazwa na IRA została zmieniona w czasie I wojny światowej, choć za faktyczną datę powstania organizacji uważa się 24 kwietnia 1916 r. (Powstanie Wielkanocne), gdy Michael Collins zreorganizował Ochotników Irlandzkich ${ }^{16}$. Organizacja jest silnie powiązana z partią Sinn Fein - podczas jej dorocznej konwencji w październiku 1917 r., IRA miała pierwszą tajną Generalną Konwencję ${ }^{17}$. Na czele organizacji stanął reorganizator, Collins, szefem sztabu został Cathal Brughy,

14 Partia, na początku, chciała dbać głównie o odbudowę gospodarczą, ekonomiczną, rozwój handlu i lokalnego przemysłu.

15 Provisional IRA, czyli Tymczasowa, zwana Provos dla odróżnienia od IRA Oficjalnej. Dziś zwykle określana jako po prostu IRA. Por. B. Bolechów, Terroryzm w świecie podwubiegunowym. Przewartościowania $i$ kontynuacje, s. 206.

16 Por. B. Roberts; IRA: korzenie i terror do 1976 roku, [w:] Encyklopedia terroryzmu, s. 573-576.

17 Por. Leksykon wspótczesnych organizacji terrorystycznych, s. 90. 
a zastępcą Richard Mulcahy. W 1919 r. proklamowano powstanie państwa irlandzkiego, czego jednak nie zaakceptowała Korona brytyjska. W $1920 \mathrm{r}$. Korona podzieliła wyspę na dwa okręgi: 26 hrabstw katolickich (ze stolicą w Dublinie) oraz 6 hrabstw protestanckich (ze stolicą w Belfaście). IRA walczyła o zjednoczoną i niepodzielną Irlandię oraz w obronie uciskanych katolików. Swą działalność zakończyła pod koniec lat 60. XX wieku wraz z podpisanym rozejmem. Wówczas dokonały się podziały w ruchu republikańskim. Zaraz po zakończeniu działalności IRA powstała PIRA, natomiast w latach 80 - CIRA i INLA.

PIRA (Provisional Irish Republican Army ${ }^{18}$ ) powstała w wyniku dezaprobaty wobec rozejmu i podporządkowania się władzy w Wielkiej Brytanii, Stormoncie i Dublinie części członków IRA. Pojawiła się w grudniu 1969 r. Naczelnym organem grupy była Rada Armii. Jej politycznym skrzydłem było Sinn Fein, które także się zradykalizowało pod koniec lat $70 \mathrm{XX}$ wieku $^{19}$. W 1972 r. podjęła utajnione rozmowy z władzami w Londynie. Ogłosiła nawet rozejm pod koniec czerwca tego samego roku, jednakże trwał on zaledwie do 10 lipca, gdyż władze brytyjskie nie godziły się na jakikolwiek kompromis ${ }^{20}$. Drugie zawieszenie broni (1975 r.) trwało 7 miesięcy. W 1977 r. ugrupowanie się zreorganizowało: zrezygnowano z hierarchizacji na rzecz budowy sieci autonomicznych komórek. Skutkiem miało być zwiększenie bezpieczeństwa członków organizacji oraz poprawienie skuteczności jej działania. Rada Armii w 1994 r. wsparła inicjatywę rozmów pokojowych Sinn Fein z władzami brytyjskimi. Zadeklarowała, że całkowicie powstrzyma się od działań, lecz już 9 lutego 1996 r. dokonali zamachu bombowego w Londynie. Zawieszenie broni przywrócono 19 lipca $1997 \mathrm{r}$. mając na uwadze wielostronne negocjacje pokojowe. Prawie rok później zgodziła się nawet na inspekcję dwóch ze licznych kryjówek, przeprowadzoną przez przedstawicieli władz ${ }^{21}$. Jednakże nie zdecydowała się na cał-

Inne nazwy to: The Provos, Tymczasowa Irlandzka Armia Republikańska; za: Leksykon wspótczesnych organizacji terrorystycznych; s. 133. Por. B. Roberts; Terror nacjonalistyczny w Irlandii Pótnocnej w latach 1976-1996.; s. 577-581.

W 1983 r. Gerry Adams, jeden z przywódców PIRA, objął przywództwo w Sinn Fein. Ogłosił, że walka podejmowana przez PIRA jest moralnie słuszna. Adams należał do IRA od 16 roku życia, pierwszą swoją akcję przeprowadził 13 sierpnia 1969 r. W PIRA na początku szkolił terrorystów oraz zdobywał broń. Był także twórcą doktryny wojny totalnej w organizacji. Uwięziony w akcji Korony przeciw PIRA, gdzie spędził prawie całe lata 70 XX wieku. W tym czasie napisał Zielona Książeczkę - podręcznik terrorysty z IRA oraz sformułował taktykę równoczesnego prowadzenia kampanii politycznej i działalności terrorystycznej (armalite and the balot box).

${ }^{21}$ Por. Leksykon wspótczesnych organizacji terrorystycznych; s. 136. 
kowite rozbrojenie i dopiero po zamachach 11 września w USA, licznych naciskach ze strony władz lokalnych 23 października 2001 r. PIRA ogłosiła swoje całkowite rozbrojenie. Nigdzie nie przedstawiła żadnych dowodów na jego dokonanie. Choć grupa zaprzestała działalności militarnej, kontynuowała działalność kryminalną. W samym 2004 r. przeprowadziła co najmniej dwa poważne napady rabunkowe na banki w Belfaście. 28 lipca 2005 r. kierownictwo PIRA ogłosiło oficjalne zakończenie walki zbrojnej, złożenie broni i rozpoczęcie walki o niepodległość Irlandii Północnej tylko metodami politycznymi. Ostatni etap rozbrojenia organizacji kontrolowała Międzynarodowa Niezależna Komisja Rozbrojeniowa. Zakończył się we wrześniu 2005 r. Liczbę członków szacuje się na około $1000^{22}$. 6 lutego 1971 r. PIRA zastrzeliła pierwszego brytyjskiego żołnierza ${ }^{23} .23$ maja tego samego roku wybuchła bomba, która rozpoczęła liczne ataki w miejscach publicznych, więc na cywilach. Do zamachów przeprowadzonych przez PIRA należy między innymi zamach na członka rodziny królewskiej, Markiza Louisa Francis Mountbattena, który zginął wraz z wnukiem i młodym majtkiem w 1979 r. Polityk został wysadzony w powietrze na swoim jachcie. W 1984 r. podczas dorocznej konferencji konserwatystów, na którym obecna była także premier Margaret Thatcher, IRA 12.10. podłożyła bombę na jednym z pięter hotelu Grand, w którym zakwaterowanych było większość polityków Partii Konserwatywnej. Rannych zostało ponad 30 osób, 4 zginęły na miejscu. Bomba została umieszczona w hotelu na trzy tygodnie przed zamachem, z ustawionym czasowym zapalnikiem ${ }^{24}$. 9 lutego 1996 r. PIRA podłożyła bombę w Londynie. Mimo ostrzeżeń policji zginęły 2 osoby, a ponad 100 zostało rannych. W rocznicę Powstania Wielkanocnego, 24.02.1996 r., podłożono silny ładunek wybuchowy pod mostem Hammersmith w Londynie (eksplodował jednak tylko zapalnik, powodując niewielkie zniszczenia).

Continuity Iris Republican Army (CIRA) powstała w połowie lat 80 XX wieku, lecz znaczenia nabrała dopiero w 1996 r., gdy sprzeciwiła się zobowiązaniu zawieszenia broni, który ogłosiła PIRA. Grupa ogłosiła wówczas, iż będzie nieustającym wrogiem brytyjskich sił, które miały okupywać Irlandię. Korzeni politycznych CIRA szukać należy w RSF ${ }^{25}$. Przejęła od niej także główny cel działalności: powołanie socjalistycznego

Por. Terroryzm, pod red. Violetty Kwiatkowskiej-Darul, s. 90-91.

23 Por. B. Blechów, Terroryzm w świecie podwubiegunowym. Przewartościowania i kontynuacje; s. 206-222.

24 Por. P. Elliot, Krwawa historia morderstw i zamachów politycznych, s. 235-240.

25 RSF (Republican Sinn Fein) to grupa odłamowa Sinn Fein, która pojawiła się na scenie politycznej w październiku 1986r. Za cel objęła przerwanie polityki absencjonizmu, 
i demokratycznego reżimu. Doprowadzić do tego miały przede wszystkim działania zbrojne. Zaznaczyć warto, że CIRA nie zaakceptowała Porozumienia Wielkopiątkowego, więc jej członkowie nie uzyskali wcześniejszego zwolnienia z więzień. W 2001 r. RSF na dorocznej konferencji ogłosiła, że CIRA będzie kontynuować działania militarne, aż do osiągnięcia pełnej samodzielności Irlandii Północnej ${ }^{26}$. Dokonali między innymi zamachów w lipcu hotelu protestanckim Enniskillen, a w październiku w koszarach wojskowych w Lisburn koło Belfastu. Rannych zostało 31 osób, a 1 żołnierz zmarł w skutek obrażeń ${ }^{27}$.

W 1974 r. po stronie republikańskiej pojawiła się Irish National Liberation Army (INLA) ${ }^{28}$. Było to lewackie militarne skrzydło Irish Republican Socialist Party (IRSP - Irlandzka Republikańska Partia Socjalistyczna) ${ }^{29}$. Powstała z byłych członków IRA Oficjalnej, którzy wystąpili z organizacji, nie akceptując zawieszenia broni w 1972 r. Najważniejszą różnicą między tą organizacją a innymi republikańskimi leży w poglądach, bowiem tylko ona oficjalnie przyznaje się do poglądów marksistowskich i żąda obalenia ustroju kapitalistycznego. Głównym obszarem jej działalności jest Belfast i obszary przygraniczne. Liczebność INLA szacuje się na 70 do 100 członków, lecz tylko część jest aktywna. Wielokrotnie współpracowała z PIRA w przygotowywaniu i przeprowadzaniu zamachów na ulsterskich protestantów. Organizacja w swojej działalności militarnej wyróżnia się tym, iż uprzedza policję o detonacji ładunku wybuchowego. Oficjalnie 22 sierpnia 1998 r. INLA ogłosiła zawieszenie broni, choć nie było zawsze przestrzegane i nawet w 2005 r. grupa nadal rekrutowała członków. Wsparcie finansowe oraz broń otrzymywała najprawdopodobniej od sympatyków z USA. W ramach grupy powstawały liczne frakcje i odłamy: Armia Wyzwolenia Ludu Irlandzkiego (IPRA), Organizacja Wyzwolenia Ludu Irlandzkiego (IPLO), INLA - GHQ, IPLO - AC, IPLO - BB. Grupa odpowiedzialna jest za liczne zamachy. W czasie swojej działalności zabili co najmniej 125 osób,

która uniemożliwiła zajęcie członkom Sinn Fein miejsc w irlandzkim parlamencie. $\mathrm{Na}$ jej czele stanęli: Ruairi O Bradaigh oraz Daithi O Conaill.

26 Por. Leksykon wspótczesnych organizacji terrorystycznych, s. 52-53 oraz Por. B. Roberts; Terror nacjonalistyczny w Irlandii Pólnocnej w latach 1976-1996, s. 577.

${ }^{27}$ Por. B. Blechów, Terroryzm w świecie podwubiegunowym. Przewartościowania i kontynuacje, s. $214-215$.

28 Inne nazwy to: People's Liberation Army (PLA), People's Republican Army (PRA), Catholic Reaction Force (CRF), Irlandzka Narodowa Armia Wyzwolenia, Ludowa Armia Wyzwolenia, Ludowa Armia Republikańska, Reakcyjne Siły Katolickie; za Leksykon wspótczesnych organizacji terrorystycznych, s. 88 .

29 Była to partia nie ciesząca się zbyt dużym poparciem, ze względu na zbyt radykalne, skrajne poglądy. 
w tym około 45 członków służb specjalnych. Stracili zaś co najmniej 20 swoich działaczy. Odpowiedzialni są za przeprowadzenie zamachów na inne grupy terrorystyczne (UDR, UVF, RUC) oraz stacjonujące w Irlandii Północnej wojska brytyjskie. 30 marca 1979 r. dokonali zamachu na Airey Neave - konserwatywny parlamentarzysta. Polityk zginął w samochodzie - pułapce ${ }^{30}$. W 1982 r. dokonali zamachu w pubie Ballykelly - zginęło 17 osób. Oskarża się także grupę o przeprowadzenie napadu i wzięcie zakładników w grudniu 2004 r. (choć grupa temu zaprzecza) ${ }^{31}$.

Od PIRA odłamała się Real Irish Republican Army (RIRA) ${ }^{32}$. Jest to jedno z najbardziej radykalnych odłamów IRA. Założona została w lecie 1997 r. przez najbardziej radykalnych członków głównego trzonu PIRA. Za nazwę przyjęli 32 County Sovereignty Committee. Odłączenie uzasadniali rzekomą zdradą starego kierownictwa PIRA prawdziwych republikańskich zasad i celów IRA z początku XX wieku. Ponad to grupa odrzuciła tzw. Deklarację Mitchella ${ }^{33}$, podpisaną przez Sinn Fein. Głównym celem politycznym organizacji było usunięcie brytyjskich żołnierzy z Irlandii Północnej oraz zjednoczenie tego terytorium z Republiką Irlandii. Po tragicznych zamachach oburzenie opinii publicznej spowodowało, iż RIRA w sierpniu 1998 r. ogłosiła zawieszenie swojej aktywności. Trwało jednak tylko do lutego 2000 r., gdy RIRA powróciła do aktywności, przeprowadzając zamachy już nie tylko w Irlandii Północnej, ale także w Wielkiej Brytanii. W maju 2001 r. RIRA została umieszczona przez Departament Stanu USA na liście międzynarodowych organizacji terrorystycznych, co skorelowało zamrożenie wszelkich aktywów finansowych jej członków. Trzy miesiące później władze irlandzkie i brytyjskie ogłosiły aresztowanie większość przywódców organizacji i rozbicie grupy - było to jednak przedwczesne ogłoszenie, gdyż w sierpniu i listopadzie RIRA przeprowadziła dwa kolejne ataki w Wielkiej Brytanii. Liczebność organizacji szacuje się na około 70 osób. Wsparcie finansowe otrzymuje prawdopodobnie od sympatyków $^{34} \mathrm{z}$ USA, ale także z Libii. W broń zaopatrują się na Bałkanach

30 Por. P. Elliot, Krwawa historia morderstw i zamachów politycznych, s. 235.

31 Por. Leksykon wspótczesnych organizacji terrorystycznych, s. 88-89.

32 Inne nazwy to: True IRA, 32 County Sovereignty Committee, 32 County Sovereignty Movement, Iris Republican Prisoners Welfare Association, Real Oglaigh Na Heireann, Prawdziwa Irlandzka Armia Republikańska; za: Leksykon wspótczesnych organizacji terrorystycznych, s. 138.

33 Deklaracja Mitchella z września 1997r. dotyczyła demokracji i odejścia od stosowania przemocy, jako metody rozwiązywania problemów społecznych i politycznych.

${ }^{34}$ Wielu sympatyków IRA mieszka w USA. Są to Irlandczycy i ich potomkowie, którzy wyemigrowali podczas wielkiego głodu. 
i w Europie Wschodniej. Podejrzewa się ich także o kontakty z Al Qaidą ${ }^{35}$. RIRA dokonała wielu krwawych ataków. W sierpniu 1998 r. przeprowadziła atak bombowy w Omach, gdzie śmierć poniosło 29 osób, a 220 zostało rannych. Kilka tygodni przed tym zamachem, organizacja podłożyła ponad ćwierćtonowy ładunek w centrum handlowym w Banbridge. Rannych zostało ponad 30 osób. Podobne akcje przeprowadziła w tym samym roku w Moira i Portadown. We wrześniu 2000 r. zaatakowali kwaterę główną służb wywiadowczych (MI6) Wielkiej Brytanii w Londynie. Kwaterę ostrzelali z ręcznej wyrzutni rakiet ${ }^{36}$. Rok później, w marcu, podłożyli ładunek wybuchowy w Centrum Telewizyjnym BBC w Londynie. W sierpniu i listopadzie dokonali ataków w Londynie i Birmingham.

\section{Po drugiej stronie: Lojaliści}

Lojaliści i unioniści to mieszkańcy wyspy walczący o to, by Ulster nie połączył się nigdy z uboższą Republiką Irlandii, a pozostał w Zjednoczonym Królestwie Wielkiej Brytanii i Irlandii Północnej, a także by nie dostał się pod władzę republikanów. Po drugiej stronie barykady dla IRA są: Loyalist Volunteer Force (LVF) i Red Hand Defenders (RHD), Ulster Defence Association/ Ulster Freedom Fighters (UDA/UFF) oraz Orange Volunteers ${ }^{37}$.

Ulster Volunteer Force (UVF, Ochotnicze Siły Ulsteru) na paramilitarnej scenie Irlandii Północnej pojawiły się w 1966 r. UVF jest kontynuacją organizacji o tej samej nazwie, założonej w 1912 r. przez Sir Edwarda Garsona. Od niej zapożyczyła nazwę i symbolikę. Ugrupowanie liczyło ok. 1000 - 1500 członków w czasach największej popularności ${ }^{38}$. Organizacja powstała typowo jako opozycja dla IRA, więc też za cel obrała unicestwianie członków i sympatyków organizacji ${ }^{39}$. Ugrupowanie ujawniło się mordując dwóch katolików i protestantkę (jak potem się okazało, nie mających związków z ugrupowaniem republikanów), ale najwięcej rozgłosu przyniosło im zamordowanie Petera Warda przez Gysty Spenc'a - lidera grupy - który został potem aresztowany i skazany na 20 lat więzienia. Były

35 17.10.2001r. media informowały o aresztowaniu na Słowacji trzech członków RIRA, którzy mieli utrzymywać kontakty i pozyskiwać wsparcie finansowe od przedstawiciela Osamy bin Lagena i dyrektora finansowego Al. Qaidy, Hamida Aicha. Por. Leksykon wspótczesnych organizacji terrorystycznych, s. 139.

37 Por. J. W. McAuley, Unionism's Last Stand? Contemporary Unionist Politics and Identity in Northern Ireland oraz K. Szulecki, Lojalizm.

39 Por. Encyklopedia Terroryzmu, s. 11-22, 141-144, 193-212, 582-583. 
żołnierz brytyjskiej armii kierował też sprawną grupą mężczyzn, która dokonała morderstw na katolikach w Belfaście (zabili co najmniej 4 osoby i ranili 2). UVF stowarzyszone jest z Red Hand Commando, które zgodziło się być integralną jej częścią. Ich politycznym skrzydłem jest Progressive Unionist Party (PUP), która bardzo mocno włączyła się w północnoirlandzki proces pokojowy, akceptując porozumienie z 1998 r. ${ }^{40}$ Podobnie do innych ugrupowań UVF łączy wiele drobnych grup działających w całej Irlandii Północnej. Ochotnicze Siły Ulsteru włączyły się w konflikty między ugrupowaniami lojalistycznymi walcząc przede wszystkim z UDA i LVF. UVF jako taktykę walki obrało podkładanie bomb, przez co ich ataki były najczęściej bardzo spektakularne. Organizacja odpowiedzialna jest za zamachy, w których zginęło ok. 547 osób. W 1969 roku członkowie UVF wzięli udział w zamachach na północnoirlandzką infrastrukturę, obalając rząd T. O’Neill'a. W grudniu 1971 r., w Belfaście podłożyli bombę w barze „McGurk's”, w wyniku wybuchu zginęło 15 osób. Trzy lata później podłożyli 3 bomby w Dublinie i 1 w Monaghan - wybuchy spowodowały śmierć 32 ludzi. Słynna jest także jedna z grup UVF - Shankill Butchers (Rzeźnicy z Shankill), która specjalizowała się w mordowaniu lojalistów z innych ugrupowań, a która w latach 70 dokonała 19 zabójstw w ciągu 19 miesięcy. Od 1972 roku terroryści UVF toczyli z IRA wojnę, składającą się z wielu „ataków zemsty”, których ofiarami byli najczęściej niewinni ludzie. W 2005 r. UVF dopuściła się co najmniej takich 4 zabójstw. Spośród grupy wyróżnia się Billy Wright - późniejszy założyciel LVF, który jest odpowiedzialny za śmierć ok. 40 katolików, głównie cywili (na konto obu organizacji). Zamordowany w więzieniu przez Irlandzką Narodową Armię Wyzwoleńczą, śmierć jego pomścili członkowie Ochotniczych Sił Ulsteru zabijając zwolnionego z więzienia byłego terrorystę IRA. Trudne czasy ugrupowanie przeżywało w latach 1976-1985, gdy wielu z członków kierownictwa było aresztowanych. Obecnie około 7\% członków Ochotniczych Sił Ulsteru stało się członkami PUP. Sam szef partii był kiedyś członkiem ugrupowania i jak sam podkreśla, uważa iż większość terrorystów powinno w obecnej sytuacji (obowiązywania porozumienia) wstąpić do partii. PUP klasyfikuje się na trzeciej pozycji pod względem wielkości partii w Irlandii Północnej, a na jej czele stoi David Ervin. Ugrupowanie rzekomo przygotowuje się do odejścia z paramilitarnego świata, jednakże jak samo ocenia, najpierw musi rozwiązać konflikt z LVF i UDA. W maju 2007 r. oświadczyło, że rezygnuje z przemocy i składa broń na ręce starszych rangą członków, co uniemożliwi do niej dostęp szeregowym człon-

40 Por. A. Finlayson, Loyalist political identity after the peace. 
kom. Jednakże nie oddało żadnej broni w ręce Międzynarodowej Komisji Rozbrojeniowej ds. Ulsteru, której przewodniczy kanadyjski generał John de Chastelain.

Loyalist Volunteer Force, czyli Ochotnicze Siły Lojalistów powstały w 1996 r. w wyniku odłączenia się od UVF, ale szersza informacja o ich istnieniu do mediów dotarła mniej więcej rok później. LVF odłączyło się nie akceptując porozumienia pokojowego $\mathrm{z}$ nacjonalistami ${ }^{41}$. Liderem grupy był Billy „King Rata” Wright (został zamordowany w więzieniu w Maze w 1997 r. Zastąpił Mark „Swinger” Fulton) ${ }^{42}$. Głównymi celem ugrupowania byli katoliccy politycy, a także cywile - głównie osoby, związane w jakiś sposób z zawiązaniem porozumienia, więc także dopuszczało się morderstw na protestanckich politykach, zaangażowanych $\mathrm{w}$ proces, uważając ich za zdrajców. W 1998 r. ogłosiła wraz z innymi organizacjami zawieszenie broni, lecz już w 2001 roku złamała je dopuszczając się morderstwa na brytyjskim dziennikarzu. Sama organizacja - jako przeciwna procesowi- nigdy nie zaangażowała się w jego uchwalenie i podtrzymanie. Wzięła w nim udział po części, i to niewielkiej, gdyż tylko poprzez oświadczenie o zawieszeniu broni, a także częściowe rozbrojenie, lecz do dnia dzisiejszego nic ponad to nie uczyniła, nie podjęła żadnych dalszych kroków ani w kierunku pełnego rozbrojenia, a tym bardziej rozwiązania organizacji ${ }^{43}$. LVF zaangażowała się natomiast w wewnętrzny spór między lojalistycznymi ugrupowaniami w Ulsterze ${ }^{44}$, co zaowocowało kolejnymi ofiarami na jej koncie. Obecnie liczebność Ochotniczych Sił Lojalistów ocenia się na ok. 250 osób. Uważa się, że obecnie jest pod kontrolą brytyjskich służb wywiadowczych ${ }^{45}$.

W 1971 r. utworzono Ulster Defence Association (UDA)- Stowarzyszenie Obrony Ulsteru, które bardzo blisko związane jest, a czasem nawet utożsamiane, z Ulster Freedom Fighters (UFF)- Bojownikami o Wolność Ulsteru. Ugrupowanie miało połączyć ulsterskich lojalistów, opowiadających się za walką zbrojną w obronie niepodległości Ulsteru. To najliczniejsza grupa terrorystyczna, która liczyła w 2005 roku około 20000 członków (w latach najwyższej popularności nawet dwukrotnie więcej). Do sierpnia 1991r. UDA działała jako legalna organizacja - ataki terrorystyczne przeprowadzała jako UFF ${ }^{46}$. W pierwszych latach swej działalności UDA or-

\footnotetext{
Por. Por. A. Finlayson, Loyalist political identity after the peace.

Por. Leksykon wspótczesnych organizacji terrorystycznych, s. 158-160.

Por. E. Jellenc, Loyalist Volunteer Force (LVF).

Por. Encyklopedia terroryzmu, s. 11-22, 141-144, 193-212, 582-583.

Więcej na stronie WWW ugrupowania: http://www.ict.org.il/

Por. J. Dee, Ulsters Twin Forces.
} 
ganizowała, poza atakami terrorystycznymi, liczne manifestacje i protesty uliczne. Odegrała jedną z głównych ról w czasie niepokojów w marcu 1972 roku. W 1974 r. zorganizowała zwieńczone sukcesem strajki w Ulsterze, a w 4 lata później utworzyła polityczną reprezentację- New Ulster Political Research Group (ULDP), którą potem przekształcono w Ulster Loyalist Demokratic Party (ULDP). ULDP w imieniu UDA walczyła politycznymi środkami o pełną niepodległość Ulsteru. Jednak w 1981 r. w wyborach lokalnych w Belfaście partia ta przegrała z kretesem, co przyczyniło się do zmiany nazwy partii na Ulster Demokratic Party (UDP). Stowarzyszenie nie przyczyniło się znacząco do procesu pokojowego, a nawet początkiem 1998 roku około 66\% uwięzionych jego członków opowiedziało się za wycofaniem z tegoż procesu. Po naciskach polityków zmienili swoje zdanie i podpisali porozumienie, lecz działania terrorystyczne toczyły się dalej aż do końca 2000 roku- tym razem przeciw UVF, z którym rozejm podpisała w następnym roku. UDA jednak, mimo podpisania porozumienia, nie oddała broni i nadal podkładała ładunki wybuchowe, a po upomnieniu ze strony władz wycofała swe poparcie dla Porozumienia Wielkopiątkowego. Udało się jednak wpłynąć na UDA i w 2005 roku ogłosiła zawieszenie broni, które utrzymuje się do dziś. Zobowiązała się rozbroić, ale dopiero wówczas, gdy uczyni to IRA. 11 listopada 2007 r. UDA wydała oświadczenie o całkowitym zawieszeniu stosowania przemocy, lecz nie obiecała natychmiastowego rozbrojenia ${ }^{47}$. W jej zamachach terrorystycznych zginęło kilkaset ofiar- do roku 1999 było ich minimum 408. Głównym celem ich ataków byli katolicy, a zwłaszcza Ci, którzy są członkami IRA. W marcu 1984 r. próbowali zabić szefa Sinn Fein, Gerry’ego Adamsa, gdy przejeżdżał przez Belfast. W lutym 1989 r. włamali się do domu katolickiego prawnika i zamordowali go na oczach rodziny ${ }^{48}$.

Red Hand Defenders ${ }^{49}$ (RHD), Obrońcy Czerwonej Ręki to ugrupowanie utworzone w 1998 roku. Skupia przeciwników procesu pokojowego, a głównym celem było udaremnienie wysiłków ulsterskich nacjonalistów dążących do zawarcia i utrzymania pokoju w regionie ${ }^{50}$. Członkowie RHD ogłosili w połowie 2001 r., iż ich ataki na katolików posiadają legitymizację w społeczności lojalistycznej, której interesów bronią ${ }^{51}$. Nieoficjalnie uważa się, że jej członkami są byli działacze oraz UDA. Ich główną takty-

\footnotetext{
7. Motywowała to tym, że jak powiedział jej przywódca, Jackie McDonald, 90\% społeczności lojalistycznej nie chce rozbrojenia.

Por. A. Brown, Terror Lojalistów w Irlandii Pótnocnej, [w:] Encyklopedia terroryzmu.

Por. Leksykon wspótczesnych organizacji terrorystycznych, s. 140.

Por. Por. A. Finlayson, Loyalist political identity after the peace.

Por. Encyklopedia terroryzmu, s. 11-22, 141-144, 193-212, 582-583.
} 
ką walki jest podkładanie bomb i podpalanie miękkich celów cywilnych, gdzie ofiarami są nacjonaliści. W lutym 2002 roku LVF i UDA próbowało przekonać RHD do rozwiązania, lecz próby te były daremne i ugrupowanie nadal istnieje. Liczebność ocenia się na mniej więcej 20 osób- jest więc to zdecydowanie mała organizacja, lecz zdolna do walki. Odpowiedzialna jest za podłożenie ładunków wybuchowych w budynku katolickiej szkoły dla dziewcząt w Belfaście. W marcu 1999 r. zorganizowała zamach bombowy na Rosemary Nelson - katolicką adwokat, broniącą praw człowieka. W 2001 roku zamordowała katolickiego dziennikarza. Początkiem 2003 roku przyznała się do morderstwa dwóch członków UDA, co czyni ją uczestnikiem konfliktu między ugrupowaniami lojalistycznymi ${ }^{52}$.

Orange Volunteer - grupa oranżystów powstała w 1998 r., gdy został wydany zakaz marszu Zakonu Orańskiego przez tradycyjną, lecz katolicką dzielnicę miasta. Organizacja optuje za pozostaniem Ulsteru w Zjednoczonym Królestwie. Składa się głównie z byłych członków UVF. Ugrupowanie przyznaje się do licznych ataków terrorystycznych skierowanych przeciw katolikom i ich interesom ${ }^{53}$. W 2000 roku ogłosiła zawieszenie broni, ale podobnie do pozostałych organizacji lojalistycznych nie rozbroiła się i nadal jest zdolna do przeprowadzania zamachów terrorystycznych. W listopadzie 2008 roku przyznała się do podpalenia klubu Edendork, w pobliżu Dungannon. Jej liczebność ocenia się na ok. 20 osób.

Omawiając działania opozycję dla IRA nie można pominąć Pastora Nie- Ian'a Paisley'a ${ }^{54}$. Pastor ulsterskiego Wolnego Kościoła Prezbiteriańskiego $^{55}$ (który sam założył) to człowiek, bez którego zapewne poziom nienawiści między grupami byłby niższy. Założył Demokratyczną Partię Unionistów (DUP)- obecnie jedną z najsilniejszych na północnoirlandzkiej scenie politycznej. W DUP i Kościele przez wiele lat rządził jednowładczo. Od 1971 r. był także członkiem parlamentu w Irlandii Północnej i Londynie, inspiratorem powstania Ulster Resistance ${ }^{56}$. Jego życie wypełnione jest demonstracjami i walką z katolicyzmem, katolikami, papiestwem i wszelakimi ugodami, a nawet kontaktami prezbiterianów z wcześniej wymienionymi - został nawet kilkakrotnie aresztowany czy usuwany z Sali obrad siłą. Był jednym z głównych przeciwników porozumienia Wielkopiątkowego oraz dopuszczenia Sinn Fein do władzy, domagając się

\footnotetext{
Por. M. La Rocque, Red Hand Defenders.

Por. Encyklopedia Terroryzmu, s. 11-22, 141-144, 193-212, 582-583.

Por. J. O. Olsson, M. Sjögren, Niż nad Irlandia, s. 239-244.

Jego drogi ku temu powołaniu wiodły przez edukację w Walii, u baptystów w USA, u Świadków Jehowy, a także u prezbiterianów w Belfaście.

56 Założonej w 1986 roku organizacji bojowej.
} 
najpierw całkowitego rozbrojenia i rozwiązania IRA- o ile mięli by w ogóle mieć jakiś głos w Stromoncie. 31 maja 2008 r. Pastor Paisley postanowił wycofać się z życia politycznego i w wieku 81 lat przekazał funkcję premiera i kierownictwo partii. Ale to tylko wspominając, gdyż o nim można by napisać osobny artykuł.

\section{Zakończenie}

Obecnie Ulster jest spokojny. Przynajmniej teoretycznie, gdyż IRA i paramilitarne organizacje lojalistów zawiesiły swoją działalność i zmierzają ku rozbrojeniu i rozwiązaniu. Nie toczą się już szermiercze pojedynki na bomby i kule między republikanami a lojalistami. Istnieją jednak starcia wewnętrzne we frakcji lojalistów, które nie dają pełnego pokoju.

2 lipca 2005 r. IRA ogłosiła zawieszenie swej działalności, a według obietnic po deklaracji republikanów podobną ogłosić miały ugrupowania lojalistów. Jednakże nie można liczyć, że takie deklaracje są gwarantem pokoju - były już niejednokrotnie ogłaszane, ale po dłuższym lub krótszym czasie, ze względu na prowokacje drugiej strony bądź brak spodziewanych rezultatów, wracano do przemocy i terroru. Pewne jest to, że obecnie obowiązujące porozumienie trwa za krótko i jest jeszcze niepewne. Naiwnością byłoby spodziewanie się po terrorystach, iż łatwo i szybko oddają broń, którą długo zbierali (tu zwłaszcza skrajne odłamy, które przecież nie zgadzają się z warunkami porozumienia i wyznaczony cel jest nadal przed nimi, więc nie dość, że broni nie oddają to może nawet liczą, że jeszcze im się przyda). Nadal ciężko o współpracę między antagonistycznymi poglądowo partiami na arenie politycznej. Istotnym problemem jest ponowne włączenie do współpracy podzielonych lojalistów.

Idealnym rozwiązaniem sprawy byłoby przyłączenie Irlandii Północnej do Republiki, zjednoczenie wyspy w jedno państwo. Można pomyśleć, że nic trudnego: uchwalić decyzję o rezygnacji z terenów na rzecz Republiki Irlandii, tak by wyspa była zjednoczona. Jednakże, taki „byt idealny" na chwilę obecną może istnieje- ale tylko w platońskim świecie idei, lecz chyba trudno znaleźć jego cień w naszej jaskini. Wiąże się to z kilkoma utrudnieniami - między innymi Republika Irlandii musiała by zliberalizować swoje prawo $^{57}$. Ze strony Wielkiej Brytanii nie jest łatwiej: w angielskim prawie istnieje paragraf stanowiący, iż status Irlandii Pół-

Istotną rolę odgrywa tam Kościół Rzymskokatolicki. Do niedawna istniał jeszcze zakaz rozwodów i antykoncepcji, a nadal istnieje zakaz aborcji i eutanazji, a to praktycznie uniemożliwia w niej życie protestantów. 
nocnej może zostać zmieniony tylko za zgodą większości jej mieszkańców, a większość to lojalni wobec Korony protestanci ${ }^{58}$. A nawet gdyby Wielka Brytania chciała zmienić prawo i zrezygnować z Irlandii Północnej, to nie byłoby to najbezpieczniejszym posunięciem ${ }^{59}$. Liczyć można, iż wspólny parlament i zmęczenie społeczeństwa ciągłymi atakami pozwoli na ustabilizowanie się pokoju na wyspie, jednakże nie jest to jego gwarant, gdyż takie próby rozwiązania konfliktu także kończyły się fiaskiem. Bojówki zarówno lojalistyczne jak i republikańskie są nadal zdolne do działań ${ }^{60}$. Mam jednak nadzieję, że Richard Rose (brytyjski politolog) mówiąc: „Wszyscy mówią o rozwiązaniu problemów Ulsteru, ale tylko nieliczni nazywają go po imieniu. Powód jest oczywisty. Problemem jest to, że nie ma rozwiązania" ${ }^{61}$, pomylił się.

A L I C J A S T A Ń C O

58 Choć może tę trudność rozwiąże czas: radykalizm katolików „skutkuje” dużo wyższym przyrostem naturalnym niż u protestantów, więc może za kilka pokoleń katolicy, optujący za aneksją Ulsteru do Republiki, będą mieli większość.

59 Należy pamiętać lojaliści nadal są uzbrojeni, gotowi do walki, a jak udowodnili przez walki między frakcyjne, są zdolni do morderstw na „swoich”, a czuliby się zdradzeni przez Koronę. ko raniąc cywila - polskiego dostawcę pizzy i grożąc następnymi uderzeniami.

${ }^{61}$ Cyt. za: V. Grotowicz, Terroryzm w Europie Zachodniej - w imię narodu i lepszej sprawy, s. 334 . 


\section{Abstract}

Conflict in the Green Island has begun in the twelfth century, when Ireland came into the United Kingdom's possession. It takes place between two antagonistic groups: Republicans (mostly native Catholics), and unionists, or loyalists (mostly the influx of Protestants). The dispute nowadays concerns the national identity of Northern Ireland. The Republicans opt for joining the territory of the Republic of Ireland, while unionists and loyalists want to stay with the Crown. Native inhabitants of the islands have been dominated politically, economically and educationally. They have fought time and again to achieve independence or unification with the Republic. Uprisings erupted (in 1641 - created anti-English, 1916 - Easter Rising, 1972 - Bloody Sunday), treaties were signed and the agreement (1973 - joint Stormont elections, the creation of the Council of Ireland, peace agreement in 1984, 1985 - an agreement and formation of the International Peace Conference (of the British - Irish relations), 1993 - the Downing Street Declaration, 1998 - Friday Agreement); despite the legislative obstacles (1652 - Act of occupation, 1691 - Treaty of Limerick, 1801 Act of Union, 1922 - Special Powers Act, 1936 - Act of public order, direct rule, 2000 - Great Britain suspended the autonomy of Ireland).

Republicans fought on the side of Irish Republican Army (IRA), which ceased its activities after the Agreement. Following the split, due to the signing of agreements, Republicans created Real IRA (RIRA), Provisional IRA (PIRA) and Continuity IRA (CIRA). Similar independent organizations are Irish Republican Army National - Liberation (INLA) and a fraction of the GHQ (INLA - GHQ). Some activists are still active in paramilitary capacities (eg. the 2009 RIRA attack). As well ascarry out criminal activities.

Loyalists and Unionists were divided from the beginning (or rather never became united). Antagonistic attitudes towards the Republicans are shared by Loyalist Volunteer Force (LVF) and the Red Hand Defenders (RHD) Ulster Defence Association / Ulster Freedom Fighters (UDA / UFF) and the Orange Volunteers. Most of them are still active. In addition to the fight against the Republicans, these groups are also fighting amongst themselves. They work in the underground, whichwell in the basement, results in criminal activities.

The conflict in Northern Ireland continues and seems difficult to solve. The society remains divided and the British law so far offers no solution, although hopefully one will be found in the future. Let us hope that there is no solution. 